Growers often feel that it is imperative to spray for control of twospotted spider mites and San Jose scale. In the low-input and organic orchards, spraying has not been necessary.

Many almond growers are now using low-input methods with similar good results. They are demonstrating that 'Nonpareil' almonds in the northern San Joaquin Valley can be successfully produced without an insecticide program. Careful winter mummy removal and mummy destruction is very important, especially when starting the transition process. Good covercrop management provides a habitat for beneficial arthropods, and biological control is enhanced if harsh pesticides are not used.

The steps to reducing pesticide inputs that we have found in this study and through the experience of successful growers are:

1. Elimination of in-season insecticide sprays by practicing good winter sanitation and mummy destruction.

2. Establishment of a good cover crop and mowing middles alternately.

3. Monitoring pests, especially scale, very carefully and not using disruptive insecticide sprays.

4. Using two Bt applications at bloom rather than an organophosphate plus oil dormant spray.

5. Using oil dormant spray if needed for scale and mite egg control.

6. Introducing the navel orangeworm parasite Goniozus legneri, if needed, when converting to lower input.

7. Harvesting promptly.

The system outlined in this report may not work for growers throughout California or eliminate all pesticides in almond orchards. However, for many growers these practices will comprise an integrated program of cultural, biological and chemical pest control. These practices also add resilience and inertia to the orchard system, so that the biological balance is resistant to disturbance.

L.C. Hendricks is Farm Advisor, Merced County Cooperative County.

\title{
Crop and farm diversification provide social benefits
}

\author{
Gary W. Johnston $\square$ Suzanne Vaupel $\square \quad$ Franz R. Kegel \\ Melissa Cadet
}

Agronomic and economic benefits of diversification have been well documented, but social benefits are less well known. Two recent California studies show that diversity of crops and farm enterprises creates year-round or extended season employment for farmworkers. Additional strategies for doing so are paced work, selective mechanization, new technologies, break-even crops and coordinating work with other farmers or local industries. Workers employed on a year-round basis or for a longer season have higher incomes, more employerpaid benefits and can provide a better standard of living for their families than their seasonal counterparts. Farmers have found many benefits from a year-round or extended employment system. Some of these are increased worker availability, increased productivity and dependability, less need for worker training and increased personal satisfaction.

For many years, growers have used crop diversification to improve soils and increase profits, but recently farmers have found additional benefits for their employees. While its agronomic and economic benefits are well known, the social benefits of diversification have received relatively little attention. Diversification strategies include rotating to other crops, double cropping and intercropping.

This article reports on two studies of crop diversification systems and employment patterns. The first study investigated the effect of multiple cropping and crop rotation systems of San Joaquin County farmers on farm employment. The second study con- sists of case studies of three farms (in the Coachella Valley, the Sacramento Valley and the North Coast) that intentionally diversified in part to provide year-round employment to seasonal workers. These studies show economic benefits for both growers and farmworkers.

Crop diversification systems also tend to be more agronomically stable and resilient. In its 1989 study, Alternative Agriculture, the National Research Council identified some of the common advantages found in most diverse systems: reduced disease, weed and insect pressures; reduced need for nitrogen fertilizer; reduced erosion; increased soil fertility and increased yields.

Diversification also can provide habitat for beneficial insects and reduces pest numbers by rendering host crops less apparent for colonization by pests. Diversification increases economic stability by reducing financial risk, stabilizing farm income, and increasing choice of farm practices.

Social benefits from diversification result from the opportunity to stabilize employment through an extended onfarm work season. The work force at most farms consists of a group of core workers (usually referred to as "permanent," "regular" or "year-round" workers) and a larger number of seasonal and casual workers, who are often brought to the ranch by farm labor contractors (FLCs). A high degree of turnover has been common among seasonal and casual workers. In a year-round operation, the employment system shifts to a more stable system with fewer workers employed over a longer period of time.

\section{San Joaquin study}

San Joaquin County commercial farmers normally grow three or more 


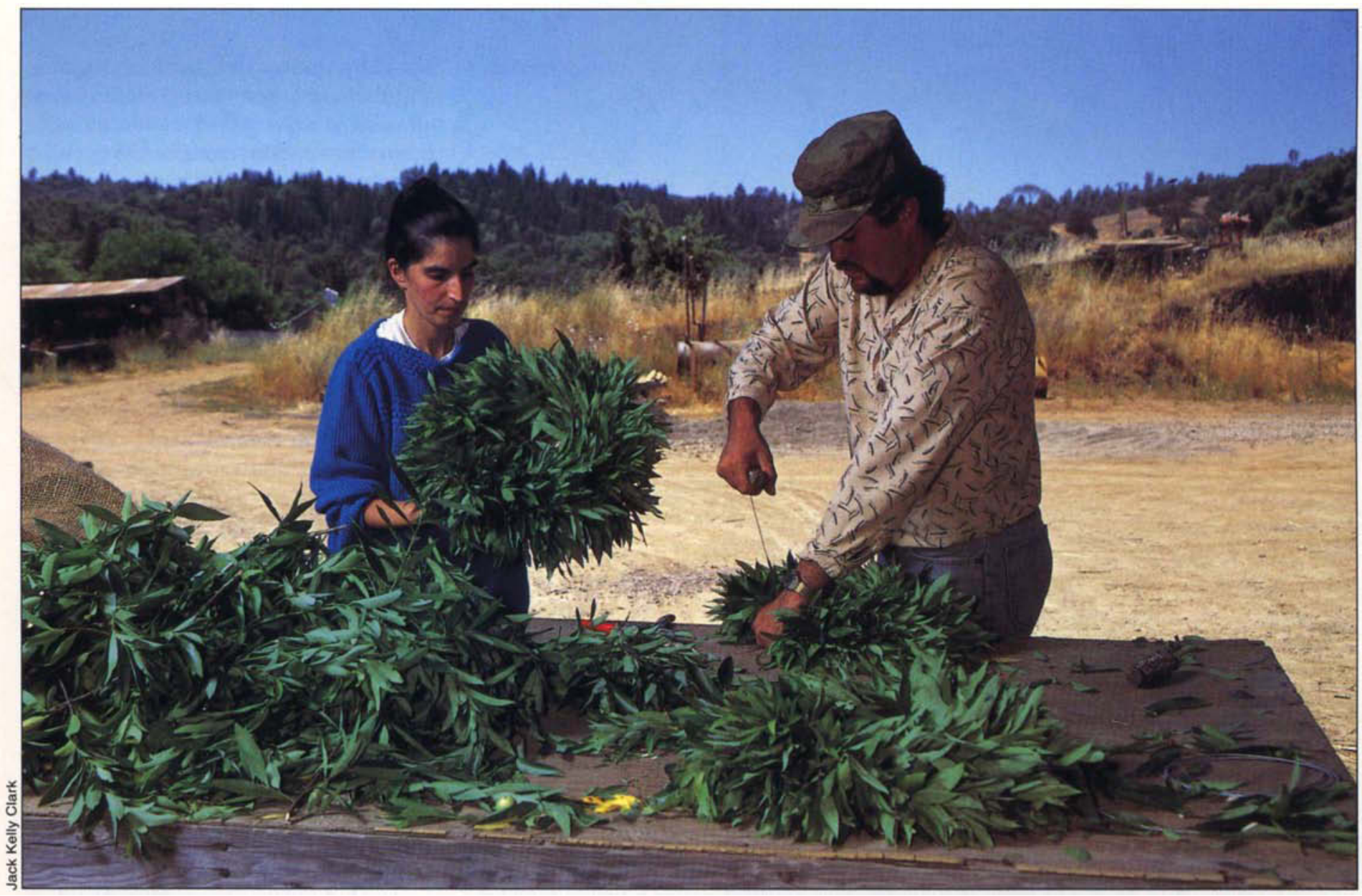

Establishing other enterprises, such as value-added processing and marketing, can extend the employment season for farmworkers. Making bay leaf wreaths, as shown above, is one example.

\section{Definitions}

Crop rotation: Practice of planting a succession of crops in the same field. Practice is used for the management of pests, plant nutrition, crop scheduling and so on.

Diversified farming: Practice of growing more than one crop (or enterprise) in any year to increase financial and biological stability of the farm.

Regular employees: Employees hired for a full production season, usually 8 or more months but possibly as little as 5 months. Most are hired in a number of succeeding years. (USDA defines regular employees as those who worked 150 days annually in farm work.)

Seasonal employees: Employees hired for specific tasks such as pruning, weeding or harvesting. May be hired direct, through FLC or by participating crop packershipper. crops, usually alternating them. In a 1989 study, 30 San Joaquin farmers were asked why they had chosen the crops they raise and how they rotate these crops. All but one of the farmers grew three or more crops in every rotation system, and all but one grew a winter cereal, often called the rotation crop, to improve the soil characteristics.

The current study expanded the 1989 study to determine the extent to which the cropping systems in San Joaquin County affect farm labor. In this follow-up study, 32 growers were asked how their crop diversification and other practices affected farm labor employment and farmworker family income (table 1). Of special interest were the length of annual employment and the number of years workers were employed by the same farmer. Most growers in the rotation study were included in the second study, and others were added to include growers whose crop mix included tree crops or grapes.
Interviews. We interviewed 32 farmers from July to September of 1992. The information gathered concerned on-farm production employment only. No labor data was collected for office staff, processing, transport or related agricultural or nonagricultural enterprises. In addition, labor activities conducted by outside entities for the planting and harvesting of fresh tomatoes and the harvesting of grain and safflower were not included in this study. These omissions should be considered when reviewing the seasonal work-force needs of these diversified farming operations.

All but four of the participants were owners or owner/operators of family farming businesses. Only one was a nonfamily corporation. Each of the 32 farming entities was a full-time farming operation and required the direct participation of the farmers interviewed.

Among all the farms, there were a total of 351 regular employees (fore- 
TABLE 1. San Joaquin County farm profile, 1989

\begin{tabular}{|c|c|c|c|c|c|c|}
\hline \multirow[b]{2}{*}{ Crop diversity } & \multirow{2}{*}{$\begin{array}{c}\text { Number of } \\
\text { farms }\end{array}$} & \multicolumn{2}{|c|}{ Acres } & \multicolumn{3}{|c|}{ Average no. workers (range) } \\
\hline & & average & range & Regular & Seasonal & FLC \\
\hline Field crops (only) & 3 & 1,040 & $320-1,500$ & $4(1-7)$ & $7(0-22) \quad 1$ & $17(0-25)$ \\
\hline Field/vegetable crops & 12 & 1,797 & $120-6,130$ & $7(1-27)$ & $10(0-51) 6$ & $60(0-210)$ \\
\hline Field/tree/vine crops & 4 & $1,687 \quad 1$ & $1,000-2,500$ & $13(5-23)$ & $154(0-553) 4$ & $45(0-130)$ \\
\hline Field/vegetable/tree/vine crops & 13 & 1,417 & $165-4,000$ & $11(2-49)$ & $56(0-330) 7$ & $70(0-203)$ \\
\hline
\end{tabular}

TABLE 2. Annual income of 351 regular employees by job classification

\begin{tabular}{|c|c|c|c|c|c|}
\hline \multirow[b]{2}{*}{ Job classification } & \multirow{2}{*}{$\begin{array}{c}\text { No. of } \\
\text { workers }\end{array}$} & \multicolumn{2}{|c|}{ Total hours worked } & \multicolumn{2}{|c|}{ Yearly wages } \\
\hline & & average & range & average & range \\
\hline Foreman or leadworker & 47 & 2,612 & $252-3,380$ & $\$ 23,631$ & $\$ 3,024-60,000$ \\
\hline General laborer (all tasks) & 97 & 1,933 & $240-2,800$ & $\$ 9,841$ & $\$ 1,140-15,000$ \\
\hline Mechanic & 11 & 2,430 & $960-3,000$ & $\$ 23,327$ & $\$ 9,600-38,400$ \\
\hline Tractor driver & 84 & 2,251 & $288-3,000$ & $\$ 13,374$ & $\$ 1,716-24,000$ \\
\hline Irrigator & 112 & 2,529 & $960-3,500$ & $\$ 12,837$ & $\$ 4,560-21,294$ \\
\hline
\end{tabular}

men, general laborers, mechanics, tractor drivers and irrigators) who worked from 5 to 12 months each year. Nearly half worked 11 or more months each year and $76 \%$ worked 9 or more months. One-third of the regular workers had been with the same farm employer 11 or more years, while $60 \%$ had been with the same employer 3 to 10 years. In addition, growers employed 3,345 seasonal workers, either through direct hiring or FLCs. The 1,488 seasonal workers hired directly by farmers worked from several days to 6 months. Most (78\%) worked fewer than 3 months, while 333 worked 4 or more months. Farm labor contractors provided 1,857 seasonal workers employment for a few days and up to several months.

There was relatively little turnover among regular workers. All of the 32 farmers interviewed stated that they relied on their present workers and foremen to refer and recruit regular workers. Every farmer stated the importance of having an experienced, loyal and skilled regular work force. Most felt that their managers, foremen and key workers were vital to the success of their operation.

Pay rates and annual incomes. Average yearly wages for regular employees (table 2) ranged from slightly under $\$ 10,000$ to almost $\$ 24,000$. Farms with higher value crops or larger acreages tended to pay the highest wages. Those with trees and vines provided more year-round employment. Foremen's and mechanics' annual incomes were almost identical, although mechanics worked fewer hours weekly (47 versus 50$)$. Irrigators working at a straight rate of pay clocked the longest hours over the shortest season for all categories of regular workers. Their hourly pay rates ranged from $\$ 4.75$ to $\$ 6.10$. Hourly rates for tractor drivers ranged from $\$ 5.95$ to $\$ 8.00$, while hourly rates for general laborers were relatively steady at $\$ 4.75$ to $\$ 5.35$.

The majority of non-FLC seasonal workers hired by farmers were paid at or near the minimum hourly wage for hoeing, weeding and thinning activities, averaging $\$ 4.50$ per hour. Piece rates were normally paid for harvest activities and ranged from an equivalent of $\$ 5$ to $\$ 10$ per hour worked.

\section{Benefits for regular workers.}

Table 3 lists benefits offered to regular workers. Employer-paid health care premiums ranged from $\$ 90$ to $\$ 200$ per month per worker and $\$ 90$ to $\$ 375$ additional for each worker's family.

Almost all farmers (30 of 32) paid bonuses. In most instances factors such as years of service, job type, num-

TABLE 3. Benefits for regular employees

\begin{tabular}{lrc}
\hline \hline Type of benefit & $\begin{array}{c}\text { Farms* } \\
\text { providing } \\
\text { benefits }\end{array}$ & $\begin{array}{c}\text { Regular } \\
\text { employees } \\
\text { receiving } \\
\text { benefitst }\end{array}$ \\
\hline Loans \& advances & $30(94 \%)$ & 97 \\
Bonus pay & $30(94 \%)$ & 81 \\
Housing \& utilities & $29(91 \%)$ & 44 \\
Health insurance & $12(38 \%)$ & 36 \\
$\quad$ (Family coverage) & $13(41 \%)$ & 32 \\
Paid vacations & $7(22 \%)$ & 23 \\
Paid holidays & $7(22 \%)$ & 7 \\
Pension/retirement & $7(16 \%)$ & 4 \\
\hline Sick leave & $5(16 \%)$ \\
\hline
\end{tabular}

- Total number of farms $=32$.

†Total number of regular employees $=351$. ber of hours worked, worker attitude and the employer's profit picture were all used to determine the amount of bonus the workers received. Several farmers stated that the bonus was in lieu of paid vacations, sick leave and/ or holidays.

Farmers provided $44 \%$ of all regular employees with housing, and more than $90 \%$ provided housing to some employees. Four out of every five farmers providing housing did not charge rent.

A majority of farmers provided some form of assistance in helping maintain and / or repair workers' vehicles. Some let the workers use their shop, some provided tools and parts, and still others had their mechanic do the repair work. A seldom-mentioned but prevalent benefit offered by 30 of 32 farmers was the practice of providing pay advances and cash loans.

None of the farmers required that the loan be in writing, nor did they charge any interest. There was no consistent relationship between benefits provided with the size of farm or types of crops grown. However, larger employers tended to have more formalized benefit programs.

Most farmers cited employee retention, maintaining good employee relations and "doing the right thing" as primary reasons for providing benefits. Several lamented that they were not able to offer more benefits and better wages to their workers: "I wish we could pay our workers $\$ 15$ per hour, but we can't afford to ... Agriculture can't pass its costs along to the customers. We can't get more for our products, and that determines what we can pay."

Labor influences on crops. When asked, "Does labor affect your choice of crops or acres grown in any given year?" no one answered in the affirmative. Nevertheless, 17 farmers avoided labor-intensive crops such as cucumbers, tomatoes and peppers. In addition, 6 out of 10 respondents grow certain crops to spread out the work for regular employees. Crops in this category include alfalfa, corn, sugar beets, tomatoes, wheat and grapes. Eight out of 10 respondents utilized hand labor in tasks for which they could use machines. Hand labor was 
used for thinning and weeding sugar beets, thinning tomatoes, harvesting grapes and harvesting asparagus. When growers did switch from hand labor to mechanization for these tasks, commonly cited factors were (1) labor unavailability, (2) high labor costs and (3) improved technology that is consistently more efficient and reliable than hand labor.

Fewer than $20 \%$ of the farmers said that labor laws and regulations affected their choice of crops grown in any given year. The commonly expressed reason was that farm labor laws and regulations literally impact all operations regardless of the crops grown. Two farmers no longer operated labor camps due to excessive housing regulations. Several farmers predicted that increased labor costs associated with labor law compliance, insurance (workers' compensation and unemployment) and health care premiums would ultimately affect the viability of all sectors of California agriculture. Meanwhile, many farmers $(69 \%)$ were using FLCs to simplify labor recruitment and the paperwork associated with a seasonal work force.

Year-round work. Nearly half of the regular employees were employed on the farm 11 or more months each year. There were essentially no breaks in employment between the beginning and end of the season. If breaks did occur, one-third of the farmers helped their workers find temporary work on other farms.

The hard economic reality of prices received for the commodities grown was the primary impediment to extending employment opportunities farmers take the prices that are offered, while many other sectors are able to dictate prices for their products. Suitable crops and cropping rotations also influenced labor needs. Climate conditions and soil types hampered extended-season activities during winter and rain. Other limiting factors included (I) workers wanting a break in employment (vacation) and (2) workers lacking needed skills.

\section{Extending employment}

Background. In 1992, in-depth case studies were conducted at farms in three different geographic regions of the state: Coachella Valley, Sacramento Valley and North Coast. The farms were $485,7,000$ and 225 acres, respectively. All three were attempting to extend employment for seasonal workers to year-round work. On average, $40 \%$ of all direct-hire employees (regular and seasonal) worked year-round at these farms.

"Profitability" was the reason given by each farmer for diversifying and increasing year-round employment. However, the path to profitability differed for each. One began a system of yearround employment because he wanted a constant supply of fresh produce to maintain his place in the market. Another started growing winter field crops when summer irrigation water became limited. The third sought opportunities to diversify into "alternative" crops and products.

Each farmer has achieved substantial diversity (table 4). The Coachella Valley farmer grew 12 vegetable, herb and field crops, some with several varieties, and operated a farm labor contracting company as well as a fruit and vegetable stand. The Sacramento Valley farmer grew eight field crops and two tree fruit crops and had a fruitdrying operation. The North Coast farmer grew wine grapes, raspberries, vegetable crops, field crops and 11 herbs; produced five value-added products from the farm; operated a mail-order business and also produced electric power on the ranch.

From this study we have identified three levels of farm diversity by crops, varieties (which affect maturity dates in fruit, nut or vegetable crops) and farm enterprises. While climate and
In addition to diversifying the crops produced, one farming operation started a mail-order business to create more year-round work. A woman packs a bay leaf wreath for shipping.

soil conditions can limit diversity in crops and varieties, enterprise diversification can be achieved in any region. Growing diverse varieties enables the grower to stay in the marketplace longer and compensates for negative market price fluctuations. Crop diversity extends seasons even further. A cropping system that includes annual and perennial crops can extend employment to a year-round basis.

Another means of extending the employment season is to establish enterprises other than production farming. New activities such as valueadded processing and marketing or nonagricultural enterprises can be added to the farming operation. The North Coast farmer makes garlic braids, sun-dried tomatoes and raspberry jam from crops that he grows. The Sacramento Valley farmer has a 
fruit-drying operation. These farm operations also include marketing components, such as mail-order sales, a roadside stand and direct sales at certified farmers' markets.

Nonagricultural enterprises enable a farmer to keep workers employed during the off-season. The North Coast farmer employs workers to make bay leaf wreaths in November and December. Other growers have started a variety of small enterprises, such as making fishing flies, during the off-seasons.

Earnings and benefits. In the three case studies, year-round workers included foremen, irrigators, tractor drivers and crew members. Foremen earned $\$ 24,000$ to $\$ 39,700$ annually, irrigators earned up to $\$ 18,800$ and tractor drivers earned up to $\$ 22,300$. Crew members earned up to $\$ 13,000$ annually at the Coachella Valley and Sacramento Valley farms and up to $\$ 20,000$ at the North Coast farm.

Two of the three growers offered health benefits to workers and their families. One paid the monthly premium for all employees who worked 60 hours during the month. The other paid the full premium for two key workers and half the premium for any worker who would pay the other half. Each grower gave paid vacations to

\begin{tabular}{lll} 
& TABLE 4. Farm diversity - 3 case studies, 1991 \\
\hline \hline Coachella Valley farm & Sacramento Valley farm & North Coast farm \\
\hline Crops & & \\
& & Barley \\
Bell peppers & Alfalfa & Beans \\
Bok choy & Corn & Oats and hay \\
Cabbage & Dry beans (3 varieties) & Wild rice \\
Herbs (2 varieties) & Safflowers & Garlic \\
Leaf lettuce (4 varieties) & Sunflowers & Potatoes (2 varieties) \\
Snap peas & Tomatoes, processing & Tomatoes, fresh \\
Spinach & Vetch for seed & Raspberries \\
Sweet corn & Wheat & Wine grapes \\
Squash (2 varieties) & Tree fruit (2 varieties) & Herbs (11 varieties) \\
String beans & & \\
Tomatoes, fresh & & \\
Wheat & & Bay leaf wreaths \\
Farm enterprises & & Garlic braids \\
Roadside stand & Fruit drying & Rackages herbs \\
Farm labor contractor & & Sun-dried tomatoes \\
& & Mail-order sales \\
& & Electric power \\
\hline
\end{tabular}

\begin{tabular}{|c|c|c|}
\hline Strategies & Benefits & Challenges \\
\hline & For growers: & \\
\hline $\begin{array}{l}\text { Have diversity, of crops, } \\
\text { varieties, enterprises }\end{array}$ & Reliable source of labor & $\begin{array}{l}\text { Establishing wages } \\
\text { for various tasks }\end{array}$ \\
\hline $\begin{array}{l}\text { Consider labor impact } \\
\text { of all decisions }\end{array}$ & $\begin{array}{l}\text { Increased productivity } \\
\text { Better-trained workers }\end{array}$ & $\begin{array}{l}\text { Workers traveling during } \\
\text { peak season }\end{array}$ \\
\hline Pace the work & $\begin{array}{l}\text { Increased personal } \\
\text { satisfaction }\end{array}$ & $\begin{array}{l}\text { Maintaining cash flow to } \\
\text { pay employees }\end{array}$ \\
\hline Use selective mechanization & $\begin{array}{l}\text { Lower unemployment } \\
\text { insurance rates }\end{array}$ & $\begin{array}{l}\text { Taking on responsibility } \\
\text { for more people }\end{array}$ \\
\hline Use new technologies & Lower workers' compensation rates & \\
\hline Plant break-even crops & Less damage to equipment & \\
\hline \multicolumn{3}{|l|}{$\begin{array}{l}\text { Coordinate with other } \\
\text { employers }\end{array}$} \\
\hline & For workers: & \\
\hline & $\begin{array}{l}\text { Better standard of living } \\
\text { Keeping children in same school } \\
\text { Settling into community } \\
\text { Eliminating migration and job searches }\end{array}$ & \\
\hline
\end{tabular}

key employees, and one provided one to four weeks of paid vacation for all employees depending on the number of years worked at the ranch. All three growers offered housing to some workers for no cost or a small fee.

Each farmer paid bonuses to workers. One paid a bonus equal to one week's salary to all employees who stayed at the farm for the full season. Another paid a $\$ 200$ to $\$ 1,000$ bonus to each employee based on farm profits and employee evaluations. The third farmer paid a $\$ 500$ to $\$ 5,000$ bonus based on farm profits. Miscellaneous benefits included paid holidays, a pension program for employees with more than 1,000 hours at the farm and use of a truck by supervisors. Upon request, one grower would deduct money from a worker's paycheck and send it to the worker's relatives in Mexico.

Discussion of techniques. Within a diversified farming operation growers have additional means for maximizing the period of employment (table 5). Farmers who succeeded in extending the employment season considered the impact on labor when making any farm production decision. Planting new crops, eliminating old crops and changing production technologies all impact labor requirements. For example, some growers avoided planting certain fresh market crops because it would mean hiring large numbers of temporary workers during the harvest season and then laying them off.

Pacing the work is another way that farmers extended employment. A farmer can often accomplish a production task quickly with a large number of short-term workers or spread out the work over a longer period of time and utilize a smaller number of workers. Staggering planting of annual crops is a method of pacing work in planting, in thinning and hoeing and in harvesting. Pruning trees and vines can be accomplished over several months. Allocating work to the offseason whenever possible means more extended-season or year-round employment. Preparing ground for planting and servicing machinery are examples of such work. Each of the 
farmers in the case studies and a majority of the San Joaquin farmers paced the work and staggered planting to spread work over a longer season.

Selective mechanization is another technique for leveling out employment over a long period of time. It may mean using less than the most advanced means of labor-saving technology, such as a tomato harvester without electronic sorting, or in some instances continuing to use hand labor. Some farmers decide against fully mechanizing a task after considering the costs and benefits of various alternatives. The money saved by full mechanization may not balance all the costs involved. The Coachella Valley farmer did not mechanize the bean harvest so that he could keep workers employed during the harvest season.

Various new technologies enable farmers to harvest crops earlier and continue production later into the season. Plastic tunnels, hot caps and greenhouse starts are examples. New seed varieties also provide early and late season crops. In some areas farmers can use these technologies to double-crop their land.

Most growers routinely use breakeven or loss crops for agronomic reasons, primarily for disease and pest control. These crops also affect employment patterns. By growing sugar snap peas, a break-even crop, the Coachella Valley farmer filled in the last gap in his annual employment pattern and kept his best workers employed continuously for 10 months rather than laying them off and risking losing them to other growers.

Growers who are unable to extend employment on their own farm can link up with other farmers and nonfarm employers who have work available during the off-season. Fifty-five percent of San Joaquin growers would like to share workers or crews with other growers, and $48 \%$ refer workers to other employers.

Advantages of a year-round employment system. Farmers have found many benefits from a yearround or extended employment system. Some of theses are increased worker availability, increased productivity and dependability, less need for

\section{Coalition promotes sustainable practices}

\section{Dave Campbell}

Funded in May 1993 by a 3-year, $\$ 2$ million grant from the Kellogg Foundation, the California Alliance for Sustainable Agriculture (CASA) is working to develop more sustainable food and agricultural systems. The coalition is the largest of 18 community-based projects funded in Kellogg's Integrated Farming Systems initiative. The initiative is designed to encourage adoption of more sustainable production methods and create agricultural systems that revitalize rural communities by creating more economic security for small farmers, fair wages for farmworkers and establishing mutually beneficial ties between urban and rural residents.

The grant provides a unique opportunity for UC to collaborate with several innovative non-profit groups in California. Members of the coalition include the UC Sustainable Agriculture Research and Education Program (SAREP), the UC Santa Cruz Agroecology Program, the Bio-integral Resource Center (BIRC), the California Institute for Rural Studies (CIRS), the Community Alliance with Family Farmers (CAFF), the Lodi-Woodbridge Winegrape Commission (LWWC), Pueblo Unido, and the Rural Development Center (RDC).

CASA seeks to build agricultural systems that provide everyone with sufficient healthy food, create just and humane social relations and promote communities suited to the constraints of their natural environments.

During its first year, CASA pursued these goals by creating guides for reducing farm chemical use, introducing integrated pest management practices to wine grape and tomato growers, conducting a sustainable agriculture leadership training program, formulating strategies to enhance local food systems and to use sustainable agriculture as a community economic development tool, conducting a farmworker housing survey, developing a library of Spanish-language materials on sustainable agriculture, and supporting a community planning process in Santa Cruz County for sustaining agriculture in the face of environmental threats and urban development.

In addition, CASA has held roundtable discussions with pest control advisors, Cooperative Extension personnel, and agriculture education teachers. These groups have begun to develop specific action plans to move the state toward sustainability.

CASA members will also work directly with farmers to find better ways of growing crops with fewer chemicals, then marketing them. For example, LWWC is a local commodity commission, which helps its 650 winegrape grower members adopt IPM and seeks markets for their products. CIRS is encouraging organic cotton production by forging an industry-wide coalition that links growers, marketers, environmentalists and pest control advisors.

CASA's steering committee also plans to expand its collaboration to benefit the wide range of California groups interested in sustainable agriculture. For example, it has allocated a portion of its funds to hire a coordinator for a statewide Sustainable Agriculture Working Group (SAWG). Modeled after similar groups around the nation, the SAWG will promote sustainable agriculture policy alternatives and work to link existing groups more effectively.

Representatives of CASA meet regularly with representatives of the other projects to share ideas and strategies.

D. Campbell is Economic and Public Policy Analyst, Sustainable Agriculture Research and Education Program, UC Davis.

For more information on CASA, contact Project Coordinator Kerstin Ohlander at (408) 459-4786. 
training workers and increased personal satisfaction (table 5). Also cited by farmers are such benefits as lower unemployment insurance rates, lower workers' compensation insurance rates and less damage to equipment.

The primary benefit of year-round employment is having a reliable source of labor. Even with the current statewide surplus of workers, growers worry about the availability of seasonal labor. Some growers are located in areas set apart from the regular geographic migrant stream. Some have important but minor labor needs when other crops are at their peak. Others fear that they may lay off trained workers only to find that the workers are employed elsewhere when they are needed again. Having steady yearround and long-term workers eliminates these worries. The benefits of a year-round or extended season work force would be even more apparent if a labor shortage occurred.

Several growers are convinced that year-round employees are more productive than short-term workers. Long-term workers require less training because they have built up skill and experience in each task on the farm plus knowledge of unique characteristics of the farm, such as low points in fields that hold water or sections that receive less water. Additionally, most workers feel motivated to work harder for an employer on whom they can depend for continuous employment.

In different ways, each farmer in the case studies and many of the San Joaquin County farmers expressed personal satisfaction from establishing a system that offers long-term employment, good wages and benefits to their employees. They described the close relationships they have with their employees: for example, taking family members to town for doctor visits, establishing savings programs and cosigning home loans.

Advantages for workers. Workers interviewed at the three case study farms felt they could provide a better standard of living for their families by working year-round at one farm. They were able to keep their children in the same school for the full year, buy items needed for school and pay other bills. Some had purchased a home or trailer. In the past, many had migrated across the state or country looking for agricultural work. All were glad to be able to depend on steady year-round employment and settle their families into the communities where they worked.

\section{Challenges of a year-round sys-} tem. As with most endeavors, there are drawbacks as well as benefits to extending the employment period. Establishing wage rates for year-round workers employed in many different tasks can be a problem. One grower established base wages for the worker's job classification (tractor driver, general labor, etc.) and never paid a worker less than that base wage. Thus, a tractor driver assigned to pruning still earned tractor driver wages instead of the lower pruning wages. However, the wage was increased if the worker was assigned to higher-paying work. Another grower always paid the same wage for the same task, even if it meant workers moved from $\$ 30$ an hour making bay leaf wreaths at piece rate to $\$ 5.50$ an hour for harvesting grapes. Most growers have found that the payroll is more difficult to track when wage rates vary for the same task or the same worker. A majority of San Joaquin County farmers paid the same rate to the same workers regardless of the different job classification in which they worked. Nine farmers varied the pay rate of workers by task, citing differences in needed skill and responsibility as reasons.

Some workers want time off to travel for extended visits to relatives during the employer's busy season. Growers told workers that they might not be rehired if they left during the peak season and advised them to travel during the off-season. Sometimes growers must discourage workers from leaving for short-term higher paying jobs.

Additional problems stemmed from increased demands on growers who feel responsible for a greater number of people. They not only must find work for employees but also must help employees with everyday prob- lems and transactions, such as going to a doctor, going to the bank, or finding medical care for their children. Farmers must also have a reliable cash flow to pay year-round workers. For each grower, however, the benefits of the year-round system balanced out higher costs and other perceived problems.

\section{Conclusions}

The findings of the two studies document that diversity of crops and farm enterprises extend the length of employment. While climate and soil conditions limit farming activities in many regions, diversified farm enterprises can extend work during the offseason in any region. To achieve yearround or extended season employment, growers must consider the labor impact as well as profitability in all production decisions. Growers find an array of benefits from establishing a year-round or extended season employment system. Workers can provide a better standard of living for their families by having continuous employment at a single location. The bottom line is that diversity makes economic sense and helps to enhance the livelihood of both farmers and farmworkers.

G.W. Johnston and F.R. Kegel are County Director and Farm Advisor Emeritus, respectively, San Joaquin County Cooperative Extension; S. Vaupel is Agricultural Economist and Attorney in Sacramento specializing in agriculture law; $M$. Cadet is Agricultural Economist and Acting Director of the Sacramento YWCA.

This study was supported in part by a grant from UC Sustainable Agriculture Research and Education Program. The authors wish to thank Personnel Management Farm Advisors Steve Sutter and Gregory Billikopf and Socorra DavilaGarcia of the EDD for assistance in the research project.

$A$ handbook for farmers, How to Stabilize Your Farm Workforce (and Increase Profits, Productivity, and Personal Satisfaction), can be purchased from the UC Sustainable Agriculture and Research and Education Program in Davis. The complete report is available upon request from that office. 